\title{
IP Commercialization Tactics in Developing Country Contexts
}

\author{
Roya Ghafele $^{1} \&$ Benjamin Gibert ${ }^{1}$ \\ ${ }^{1}$ Oxfirst Limited, Oxford, UK \\ Correspondence: Roya Ghafele, Director, Oxfirst Limited, Oxford Science Park, John Eccles House, Robert \\ Robinson Avenue, OX44GP Oxford, UK. E-mail: info@oxfirst.com
}

Received: February 24, 2014

Accepted: March 14, $2014 \quad$ Online Published: May 3, 2014

doi:10.5430/jms.v5n2p1

URL: http://dx.doi.org/10.5430/jms.v5n2p1

\begin{abstract}
Despite the closing gap in patent ownership in technologically sophisticated developing countries, a significant gap in patent commercialization remains. The same economies that are becoming global leaders in terms of the size of their patent portfolios suffer from a lack of corresponding increase in their monetary returns from innovation. While traditional bilateral licensing remains an important mechanism to monetize patents, there are a number of other mechanisms available to extract value from patents. These include patent securitization, patent exchange platforms, public-private technology transfer initiatives, and public support in patent litigation procedures. With reference to multiple case studies this paper outlines these mechanisms and discusses the ways in which patent commercialization can be improved in the developing world. Significantly, patent commercialization can be stimulated using both market mechanisms and carefully structured government support. It is this combination of a positive institutional environment for patent commercialization and an awareness of the market mechanisms available to innovators that will promote stronger technology markets and generate more financial returns from patents in the developing world.
\end{abstract}

Keywords: patent strategy, patent commercialization, secondary markets for patents, emerging markets, technology transfer centres, patent intermediaries

\section{Introduction}

The TRIPS Agreement, by ensuring stronger patent regimes around the world, has globalized the patent system and stimulated greater cross-border trade in knowledge assets. (Note 1) Technology transfer, a term still not defined in the World Trade Organization's (WTO) framework, has come to be seen as the primary strategy for developing countries to gain access to much needed, but legally protected, knowledge assets owned in developed economies (Bell 2012; Pueyo et al. 2011; (Teece 1977; Liu 1995; Bozeman 2000; Hewitt-Dundas 2011; Saggi 2002; Schrank 2004). However, while technology transfer from developed to developing countries remains a major issue in global innovation governance debates, it is equally important to recognize the alternative patent commercialization techniques available to actors in the developing world itself. By recognizing these alternatives, developing nations may eventually begin to close the gap that prevails in patent commercialization globally.

As patent ownership grows, it is increasingly significant to identify the various mechanisms available to rights holders in developing countries to commercialize their own patents. This study reviews several patent commercialization strategies in order to emphasize the ways that patents can be used to generate innovation and growth within developing nations. Essentially, we are asking: what methods enable developing country innovators to commercialize their technology within their own nation and abroad? In doing so, we explore the variety of patent monetization techniques that exist and assess the extent to which they promote active markets for technology in developing countries. This method contrasts with more common approaches that investigate how developing countries can attract Foreign Direct Investment (FDI) from Multinational Corporations (MNCs) through the enforcement mechanisms of a strong patent regime.

The role of patents in developing countries, defined in the contest of this paper as middle- and low income countries is primarily conceived through the prism of the influence of 'weak' vs. 'strong' patent regimes (Gould and Gruben 1996; James 2001; Lanjouw and Lerner 1997). While the rule of law is certainly a constitutive element of functioning markets, this research does not assess mechanisms that promote uptake of patent commercialization tactics. (Maskus and Reichman 2004; Helfer 2004; Hassan et al. 2010). Accordingly, patent owners in developing countries tend to be conceptualized as passive receivers of proprietary innovation developed elsewhere rather than as 
active participants in an increasingly global economic order.

While we recognize the institutional constraints that patent owners may face, and the fact that developing countries are lagging behind the developed world in fostering genuinely domestic innovation, we argue that there are ample opportunities for patent owners in developing markets to leverage their patents to promote economic growth. We suggest that the patent ownership divide may be closing, but that substantial differences persist in the extent of patent commercialization in various countries. Developing countries that are becoming global leaders in patent ownership seem to lag behind in relation to the financial returns they are able to generate from their innovations. While bilateral licensing remains a valuable mechanism to extract value from patents, we posit that developing countries can capitalize on both market- and policy-driven patent commercialization mechanisms in order to promote active technology markets. These include patent securitization, patent exchange platforms, public-private technology transfer initiatives, and public support in patent litigation procedures. A combination of institutional support and the adoption of alternative commercialization processes should help developing nations promote stronger technology markets and generate more financial returns from patents in the future.

The paper is structured as follows. First, International Monetary Fund (IMF) licensing statistics are reviewed for a sample of twenty countries in order to increase understanding of the degree of patent commercialization internationally. Then, statistical evidence from the World Intellectual Property Organization (WIPO) database on global patent stocks is used to demonstrate the growing ownership of patents in developing nations. The WIPO data suggests that the patent divide, defined as the gap in patent ownership between developed and developing countries, is gradually narrowing for the more technologically sophisticated developing countries. However, a significant divide persists in terms of patent commercialization. While this may be driven by differences in patent quality around the globe, we focus here on the relevance of patent commercialization options in addressing this divide. The second section briefly outlines the key concepts of patent monetization and presents multiple case studies in order to identify some of the instruments available to commercialize patents.

\section{The Commercialization of Intellectual Property}

\subsection{Intellectual Property and Technology Commercialization}

The institutionalization of property rights is a constitutive element of a market economy. Patents are typically conceived as a means of reducing market failures associated with knowledge assets that are non-excludable and non-rivalrous in consumption (Merges 1994). The introduction of property rights over intangibles renders embedded and tacit knowledge codifiable, functional and manageable. In general, the introduction of property rights enables the generation of surplus value. Take the example of land. One can still extract 'use value' from land, such as collecting fruits and game, without property rights. However, the introduction of property rights over land enables additional revenue streams not necessarily related to its primary use value, such as rent and sale. In a similar manner, the introduction of patents allows to not only extract value from its primary use, but also through a variety of secondary commercialization mechanisms.

By disaggregating knowledge and invention from its owner, patents are legally packaged for the transfer of ownership through a transaction (May 2002). Patents institutionalize a commercial paradigm over knowledge relations and can thus be seen as a cornerstone of the knowledge based economy. To discuss to what extent it is legitimate to commercialize knowledge relations and where the boundaries of knowledge privatization should be set is not the subject of the paper. This said the privatization of knowledge relations is an important political issue that should not go unnoticed.

Patents are the currency of the knowledge-based economy. Without a functioning patent system, knowledge - like labour - cannot be alienated, and its value is limited to the ability or inclination of the innovator to put it to work. Such a system disadvantages innovators by inhibiting their ability to monetize their ideas, which they can do under a patent system even if they lack the time, skills or resources to commercialize it themselves. The patent system places knowledge and ideas in a market system, acting simultaneously as a legal framework that facilitates disputes over ownership and infringement, thus lowering the cost of patent enforcement for individual firms. From a social perspective, the absence of a functioning patent system that can be observed in many developing countries annihilates immeasurable values of knowledge and ideas by providing no system through which to realize their tradable worth (May 2002).

The perspective adopted here of patents as an enabling mechanism for developing nations rather than a defensive right turns traditional understandings of patents on their head. However, both within academia and business there is an emerging trend of recognizing the value proposition of patents through an intangible assets perspective (Ortiz 
2011; Fukugawa 2012; (Chesbrough 2006; Arora, Fosfuri, and Gambardella 2001; Merges 1999; Feldman and Florida 1994). Patents are seen as an emerging asset class that can be proactively managed, developed, and nurtured to enhance business value (Malackowski 2006; Reilly and Schweihs 2004). It is important to recognize that, despite the recent turn towards perceiving patents as a tool that can be proactively managed by developing nations, there are a number of legitimate concerns regarding the precise relationship between patents and innovation. (Helpman 1992; Chen et Puttitanun 2005) This type of research is needed to disentangle the web of factors that influence the relationship between IP protection and innovation. For example, it has been shown that the relationship between patent protection and product innovation in developing countries depends on the channel of production transfer: Foreign Direct Investment (FDI) increases the rate of product innovation but imitation does not (Edwin L.-C. 1998).

Another important question is the extent to which patent commercialization techniques will foster research and technology transfer without the presence of adequate institutional conditions to generate knowledge assets. It is logical to assume that, without these assets, the ability to monetize patents will only have a marginal (if any) impact on innovation and growth. However, understanding the range of options available to monetize patent assets is still a valuable step in this process. Conceptualizing patents as enabling is particularly important for developing countries often considered victims of international patent harmonization (Bettig 1996; May 2009). Patents can be an instrument that empowers patent owners in developing countries because it increases the economic advantages derived from property rights and precipitates a governance structure owned and operated by innovators. Yet it is important to move beyond simple conceptions of patent ownership and protection and towards a deeper understanding of how patents can be effectively managed.

\section{The Intellectual Property Commercialization Divide}

\subsection{The Global Distribution of Licensing Revenue}

In order to get a more detailed picture of the global licensing landscape, a set of 22 countries was selected for analysis. The selection process sought to ensure that a variety of income levels and geographic locations were represented in the study. This was done to provide a more differentiated understanding of the global licensing landscape. The selection also sought to emphasize large emerging economies that represent significant international markets. In making this selection we also sought to represent a diverse range of geographies in order to avoid focusing on a single region. Our findings suggest that global licensing revenues continue to grow. However, revenues remain unequally distributed across nations. Interestingly, the gap in licensing revenues is stronger than the gap in patent ownership. Though the growth in licensing revenues can be seen as an indicator of the greater efficiency of technology utilization, we still observe strong differences in the global distribution of licensing revenue.

\subsection{Data Limitation}

The International Monetary Fund (IMF) data used in this classification is not ideal because it reflects licensing and royalty revenues received from a range of forms of intellectual property, such as patents, trademarks, business franchises and copyright. The figures do not indicate the proportion of revenue and payments attributable to patents alone. The share of patents in the licensing and royalty figures is unlikely to be homogeneous across all countries. This complicates cross-country comparison of licensing fees and patent application data. Balance of payment data for license fees can also be misleading because it captures many intra-firm transactions that are not specifically tied to knowledge creation and patent monetization. For example, a country may have a high level of receipts because of a favourable tax environment or because of the prevalence of profit-shifting techniques such as transfer pricing. Finally, the quality of patents is very likely to vary across countries and is significant in determining the amount of patent revenues. All of these points are important limitations to the conclusions that can be drawn from this data. However, it is the best data currently available worldwide and it still offers valuable insights on capital flows associated with various forms of patents. While certainly not sufficient to establish a causal relationship between patent ownership and licensing revenue, it provides a useful illustration of the patent commercialization divide. It is an interesting fact in itself that the only data available on monetary streams associated with patents does not offer clearly disaggregated indicators. This may reflect a lack of awareness regarding the need to grasp the value of patents in terms of its commercial relevance. The majority of existing innovation indexes continue to measure innovation output primarily in terms of patents held rather than according to the economic value of those patents. This is unfortunate because it suggests to policy makers in the developing world that stimulating higher levels of patent filings is sufficient to foster domestic innovation. Patent quality and patent strategy, discussed later, is an equally significant concern. 
Table 1. Royalty, license fees received and paid and balance of payments 2012

\begin{tabular}{|l|r|r|r|}
\hline Country & Royalty, Licenses Received & Royalty, Licenses Paid & Balance of Payments \\
\hline USA & $\$ 124,182,000,000$ & $\$ 39,889,000,000$ & $\$ 84,293,000,000$ \\
\hline Japan & $\$ 31,892,291,572$ & $\$ 19,897,558,093$ & $\$ 11,994,733,479$ \\
\hline Germany & $\$ 13,870,402,170$ & $\$ 12,242,599,905$ & $\$ 1,627,802,265$ \\
\hline U.K. & $\$ 12,462,124,293$ & $\$ 8,474,918,702$ & $\$ 3,987,205,591$ \\
\hline France & $\$ 12,407,943,395$ & $\$ 9,574,384,043$ & $\$ 2,833,559,352$ \\
\hline Italy & $\$ 4,059,555,010$ & $\$ 6,048,865,965$ & $-\$ 1,989,310,955$ \\
\hline Republic of Korea & $\$ 3,435,500,000$ & $\$ 8,386,900,000$ & $-\$ 4,951,400,000$ \\
\hline China & $\$ 1,044,102,041$ & $\$ 17,748,983,437$ & $-\$ 16,704,881,396$ \\
\hline Russian Federation & $\$ 664,200,000$ & $\$ 7,629,200,000$ & $-\$ 6,965,000,000$ \\
\hline Brazil & $\$ 510,711,776$ & $\$ 3,666,480,099$ & $-\$ 3,155,768,323$ \\
\hline India & $\$ 321,445,174$ & $\$ 3,990,055,617$ & $-\$ 3,668,610,443$ \\
\hline Poland & $\$ 229,000,000$ & $\$ 2,332,000,000$ & $-\$ 2,103,000,000$ \\
\hline South Africa & $\$ 67,324,145$ & $\$ 2,016,729,953$ & $-\$ 1,949,405,808$ \\
\hline Indonesia & $\$ 58,049,486$ & $\$ 1,800,089,222$ & $-\$ 1,742,039,736$ \\
\hline Kenya & $\$ 32,121,765$ & $\$ 31,781,529$ & $\$ 340,236$ \\
\hline Bolivia & $\$ 8,525,088$ & $\$ 42,725,000$ & $-\$ 34,199,912$ \\
\hline Philippines & $\$ 8,000,000$ & $\$ 504,000,000$ & $-\$ 496,000,000$ \\
\hline Morocco & $\$ 1,878,245$ & $\$ 56,845,014$ & $-\$ 54,966,769$ \\
\hline Botswana & $\$ 222,528$ & $\$ 13,486,394$ & \\
\hline
\end{tabular}

(Source: World Bank Development Indicators)

The table indicates significant differences in the total economic value of royalties received and paid. Whereas high-income nations pay and receive royalties in the range of trillions of \$US, low-income countries perform extremely poorly in comparison. It further suggests that low-income countries may remain marginalized in the international patent system, despite being increasingly integrated into the legal and economic framework that supports it. To argue that patents have negative side effects for developing countries in general does not appreciate that they may, in fact, suffer from a lack of exposure to and experience with this relatively new international system of proprietary innovation. While developing countries do currently suffer from lower technological capability and less valuable patents, greater experience with alternative patent monetization mechanisms could be a step towards addressing the current gap in licensing revenues.

This makes the majority of the surveyed countries net importers of patents. This is not necessarily a bad thing. If, for example, the imported patents help domestic actors leverage foreign innovation as an engine of economic growth, then it can have a strong impact on the local economy. However, if the country owns large patent portfolios itself but pays more in licensing than it receives, then it is likely subject to the underlying quality of the patent portfolio, that they are not adequately commercializing their patents. These two possibilities are not mutually exclusive. A nation may effectively leverage imported patents but remain ineffective at trading its own patents. The accumulation of patent portfolios for other strategic reasons such as a deterrent to litigation, a bargaining chip during negotiation, and as a signal for start-up financing will also impact these figures.

\subsection{A Narrowing Patent Ownership Divide}

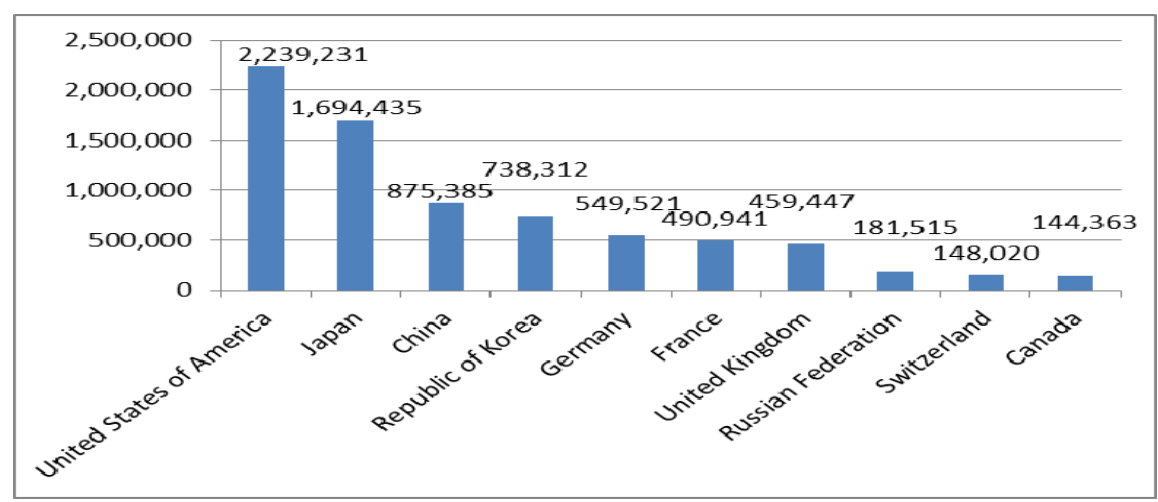

Figure 1. Patent grants by patent office and origin and patents in force, 2012

(Source: World Intellectual Property Organization Statistical Database) 
What is most striking about Figure 1 is that China, the Republic of Korea and the Russian Federation hold the third, fourth and eighth largest patent portfolios respectively, but dispose of negative Balance of Payments in terms of patent licensing and royalty revenues. The USA, which drastically outperforms all other nations in terms of royalties received, also holds the largest portfolio in terms of patents in force. This may be influenced by the variety of patent commercialization techniques evident in the USA.

\begin{tabular}{|c|c|c|c|c|}
\hline Country & Patents in Force & Patents Filed $\quad$ - & Resident Applications (\%) & R\&D Expenditure (\%) GDP \\
\hline USA & $\begin{array}{r}2,239,231 \\
\end{array}$ & 253,155 & 48 & 2.77 \\
\hline Japan & $1,694,435$ & 274,791 & 82 & 3.31 \\
\hline Germany & 549,521 & 11,332 & 72 & 2.84 \\
\hline U.K. & 459,447 & 6,864 & 43 & 1.77 \\
\hline France & 490,941 & 12,913 & 88 & 2.25 \\
\hline Italy & 68,000 & 5,625 & 86 & 1.25 \\
\hline Republic of Korea & 738,312 & 113,467 & 74 & 3.65 \\
\hline China & 875,385 & 217,105 & 66 & 1.84 \\
\hline Russian Federation & 181,515 & 32,880 & 68 & 1.12 \\
\hline Brazil & 41,453 & 2,830 & 13 & 1.16 \\
\hline India & 42,991 & 4,328 & 17 & $\mathrm{n} / \mathrm{a}$ \\
\hline Poland & 41,242 & 2,484 & 74 & 0.77 \\
\hline South Africa & 112,339 & 6,205 & 11 & $\mathrm{n} / \mathrm{a}$ \\
\hline Indonesia & $\mathrm{n} / \mathrm{a}$ & $\mathrm{n} / \mathrm{a}$ & $\mathrm{n} / \mathrm{a}$ & $\mathrm{n} / \mathrm{a}$ \\
\hline Kenya & $\mathrm{n} / \mathrm{a}$ & 76 & 5 & $\mathrm{n} / \mathrm{a}$ \\
\hline Bolivia & $\mathrm{n} / \mathrm{a}$ & $\mathrm{n} / \mathrm{a}$ & $\mathrm{n} / \mathrm{a}$ & $\mathrm{n} / \mathrm{a}$ \\
\hline Philippines & $\mathrm{n} / \mathrm{a}$ & 1,111 & 1 & $\mathrm{n} / \mathrm{a}$ \\
\hline Morocco & $\mathrm{n} / \mathrm{a}$ & 979 & 11 & 0.73 \\
\hline Botswana & $\mathrm{n} / \mathrm{a}$ & $\mathrm{n} / \mathrm{a}$ & $\mathrm{n} / \mathrm{a}$ & $\mathrm{n} / \mathrm{a}$ \\
\hline
\end{tabular}

Figure 2. Patents in force, patents filed, applications by residents in 2012 and R\&D expenditure as percentage of GDP in 2011

(Source: World Intellectual Property Organization Statistical Database, World Bank Development Indicators)

Figure 2 suggests that developing countries are catching up in terms of patent filings. Obviously, countries like the United States hold traditionally important portfolios, but emerging economies like China, the Republic of Korea and the Russian Federation are rapidly catching up and aggressively filing patents so to grow their portfolios. In most cases this is correlated with important R\&D investments. A country like the Republic of Korea simply spends a lot of money on research and development and by consequence can afford to file portfolios of important size. But then again, the R\&D spending of a country like the Russian Federation is just a bit over one percent of its GDP and still important filing rates can be observed. What is important to note is that in many developing countries patents are filed by residents, which suggests genuine innovation. Though this data does not indicate which country or income group these inventors are from, it suggests a stronger focus on indigenous technology alliances and collaboration. This is a positive development since a higher level of collaboration should help stimulate technology transfer and knowledge spill overs.

In terms of our sample, it is interesting that in the Russian Federation, Poland, the Republic of Korea and China patent applications are to a large extent filed by residents. Roughly $74 \%$ of patent applications in Poland and the Republic of Korea are filed by residents. China has a higher rate of resident to non-resident applications than the USA, with $66 \%$ of applications filed by residents.

China is an informative case for developing nations. Though patent law has only existed since 1985, the Chinese government has promoted an 'ecosystem of incentives' for individuals to file patents in order to stimulate domestic innovation. Workers and students who file patents earn residence permits to live in attractive areas, while professors increase their chances of winning tenure. Cash bonuses are offered in some cases, the government covers filing costs in others. Corporate income tax can be cut over $10 \%$ for companies filing multiple patents. This public sector drive has consequences in the private sector as well: the potential for tax reductions and government contracts pushes firms to offer employees incentives to patent. Huawei pays employees patent-related bonuses of $\$ 1,500$ to $\$ 15,000$, partially contributing to its meteoric rise to the top firm for international patent filings.

Yet, China remains far behind all of these countries in terms of licensing revenue. This may be due to a time-lag between patent ownership and monetization. However, it is more likely the result of policies that incentivize the 
filing of patents without adequately emphasizing the importance of patent quality for generating licensing income. These incentive systems precipitated a rush in patent filing, often for inventions of little or no value. A Thomson Reuters survey in China shows that only one fifth of patent professionals believe Chinese patents are of high quality, a smaller proportion than any other region in the world included in the survey. (The Economist, 2010) Developing nations must balance incentives to file patents with threshold standards for patent quality in order to truly capitalize on IP as a value generator.

\begin{tabular}{|c|c|c|c|c|c|}
\hline Country income group & $\nabla$ & \begin{tabular}{|l|l|} 
Number of Applications & $\nabla$ \\
\end{tabular} & Resident share (\%) & \begin{tabular}{|l|l|} 
Share of world total (\%) & - \\
\end{tabular} & Average Growth (\%) \\
\hline Year & & 2012 & 2012 & 2012 & $2007-2012$ \\
\hline High-income & & $1,513,500$ & 61.3 & 64.5 & 0.6 \\
\hline Upper middle-income & & 754,700 & 74.4 & 32.1 & 17.9 \\
\hline Lower middle-income & & 69,000 & 22.1 & 2.9 & 2.5 \\
\hline Low-income & & 10,500 & 84.1 & 0.4 & 3.8 \\
\hline World & & $2,347,700$ & 64.5 & 100 & 4.7 \\
\hline
\end{tabular}

Figure 3. Patent application share by income group \& filing rates by residents, 2012

(Source: World Intellectual Property Organization Statistical Database)

Global data from the WIPO database summarized in Figure 3 furthermore suggests that the gap between domestic and foreign patent applications is closing in middle-income countries. Thus, more and more developing countries are taking advantage of the international patent systems to give their own technology markets a boost. Compared to 61.3 of patent applications filed by residents in high-income countries, the upper middle-income group exhibits a $74.4 \%$ resident filing rate. In contrast, lower middle income countries continue to experience a significant disparity, where residents file only $22.1 \%$ of patent applications. In terms of volume of patent filings developing countries, be they low or middle income countries are rapidly catching up. While between 2007 and 2012 high income countries patent filings grew by only $0.6 \%$, upper middle income countries experience a growth rate of $17.9 \%$. That same rate was $2.5 \%$ in lower middle income countries and $3.8 \%$ in low income countries. This means that nearly $60 \%$ of patents filed in 2012 came from the developing world, defined as middle income and low income countries. With these types of growth rates it may be assumed that the filing gap will quickly be closing in the years to come.

\subsection{A Growing Patent Commercialization Divide}

Data from our sample suggests that important gaps in patent commercialization persist. This is the case both in terms of the volume of licensing and royalty revenues and the direction of cash flows associated with innovation. Developing countries seem to be significantly marginalized in this aspect of the international system. Analysis of the entire World Bank dataset for all countries and income categories in 2009 (including those outside our sample) confirms this hypothesis.

Table 2. Licensing and royalties balance of payments by income group, 2012

\begin{tabular}{lrrr} 
Income Group & Royalties, Licenses Received & \multicolumn{1}{c}{ Royalties, Licenses Paid } & \multicolumn{1}{c}{ Balance of Payment } \\
\hline High Income & $\$ 237,309,868,237$ & $\$ 209,164,160,360$ & $\$ 28,145,707,877$ \\
\hline Middle Income & $\$ 4,473,163,968$ & $\$ 44,957,101,847$ & $-\$ 40,483,937,879$ \\
\hline Low Income & $\$ 63,957,821$ & $\$ 103,112,296$ & $-\$ 39,154,474$ \\
\hline
\end{tabular}

(Source: World Bank Development Indicators)

A variety of factors may impact these differences in patent commercialization. The level of FDI, the technological skill base within the country, education, inflation and exchange rates are only a few to name. These factors cannot be isolated. This is also not necessary for the purposes of this paper, which restricts its focus to the various patent commercialization mechanisms that can be used to alleviate this gap. However, this is an important topic for future research.

An important consideration affecting patent commercialization potential is that of patent quality. The commercial value of a patent depends on its feature, which in turn relies on patent validity in terms of its claims (Noveck 2006), but also includes important measures such as forward citations, scope of claims, prior art, extent of patent family, 
and applicable territories. Poor quality patents will hinder the ability to monetize them because, whether or not a country has suitable policies, there will be no market demand for patents which are very likely to be invalidated in the course of a potential litigation. The USA and other developed economies have had significant difficulties with patent quality, which results in litigation costs exceeding returns from patents and inhibit the development of upstream innovations. As emerging economies such as China, India and Brazil strengthen their patent systems, they have adopted more stringent standards towards qualification criteria such as novelty and disclosures of origin (Reichman 2009). In this manner, they hope to avoid the issues that have arisen in developed economies.

\section{Instruments of Patent Commercialization}

Commercialization mechanisms were selected on the basis of emphasizing the diversity of options available to innovators in the developing world. The different strategies available to extract greater value from patents range from purely market-driven initiatives to public-private partnerships. While patent commercialization strategies necessarily involve private actors, the extent to which they rely on public policy support differs. Significantly, policy makers can help stimulate purely market-driven approaches by identifying relevant stakeholders and increasing awareness of the range of tools at their disposal. However, it is important to note that these market-driven monetization strategies rely on more sophisticated secondary technology markets that take time to develop. The obstacles encountered in this process - including concerns about liquidity, transparency and standardization - are an important topic of academic debate and are elaborated on by (Hagiu and Yoffie 2013, Dang and Motohashi 2012, Hagelin 2002, McClure 2008, Millien and Laurie 2007, and Ziedonis 2004. This range of options to monetize patents from market to public-private arrangements informs our analytical framework. The patent monetization cases discussed below begin at the private end of the spectrum and proceed onto those initiatives that require a greater amount of policy support.

\subsection{Patent Securitization}

Securitization has emerged as a major financial innovation in the past thirty years (Merges 1999) and the securitization of patents has received the attention from financial service firms (Yanrong 2013; (Malackowski, 2006). In the simplest terms, patent securitization enables a company to pool certain rights and sell the future cash-flows associated with them for an immediate lump sum. The most valuable result of patent securitization is the unlocking of liquidity without committing the company's credit, non-patent assets or issuing dilutive stock (Borod 2005).

Innovating firms in the developing world often face significant challenges in raising capital to commercialize their innovations due to a lack of trust of international investors in developing markets. Patent securitization presents a valuable opportunity for firms in developing economies to monetize their assets and improve capital liquidity because it distinguishes between the firm itself and the patents in question. When securitized patent portfolios are decoupled from the underlying firm, which enables cash to be raised on the basis of the patents themselves rather than the underlying company. This enables investors to hedge risks associated with investment in innovation while permitting patent owners to access the capital necessary to commercialize their inventions. Innovating firms in the developing world with fewer tangible assets to back debt financing can now rely on their intangibles to raise much needed funding. Securitization effectively permits firms that may not be of a high investment grade to access capital through the international market; securitization repositions financial risk into a set of financial instruments such as Special Purpose Vehicles (SPV) or Bankruptcy Remote Entities (BRE) (Anson 2005). By legally isolating the assets that are generating cash flows, investment credit ratings can be massively improved.

While patent securitization is historically more common with trademarks and copyrights, with patent securitization representing around 13\% of total deals and only 9\% of volume exchanged between 1997 and 2004 (Kirsh 2005), our focus here remains on patent securitization. Patent securitization has been almost exclusively associated with pharmaceutical patents since the royalty streams are typically more stable than other technologies. However, as secondary patent markets mature and valuation processes become more transparent and standardized, it is highly likely that securitization will diffuse to other technology sectors. The first case of patent securitization, established by Royalty Pharma AG in 2000, has received enormous amounts of academic attention. Founded on royalty payments for Yale University's Zerit HIV drug patent that were licensed to Bristol Myers Squibb through a BRE, $\$ 115$ million was issued in debt and equity securities in three tranches (Calderini and Odasso 2008). Despite its early amortization, this deal stands as an important landmark in patent securitization. Three years later in 2003 another landmark case occurred when Royalty Pharma struck a securitization deal based on a pool of thirteen drug patents, including four drugs still waiting on FDA approval (Hillery 2004). Receiving a AAA rating from both Moody and Standard \& Poor, \$225 million in variable funding was raised. By pooling the patents, uncertainty regarding poor royalty performance was mitigated by a diversified portfolio. The issuance of a single tranche along with a robust insurance system also enabled this more successful securitization to raise patent-backed equity (Calderini and 
Odasso 2008).

Patent securitization can raise liquidity without relying on company finance reports, incurring income tax on proceeds, creating new debt on balance sheets and, usually, without losing the right to manage and exploit the patents in the future (Borod 2005; Watanabe 2004). Securitization can simultaneously lower the cost of capital, limit credit exposure and parcel risk across various patents. Pooled patent securitizations also enable innovators in the developing world to gain access to much needed finance by aggregating a large variety of patent rights into a single portfolio, and thus reducing the investor risk associated with a single patent.

There are numerous difficulties associated with a patent securitization, such as valuation, royalty forecasting, principal-agent problems and a lack of secondary markets for patents that are elaborated by Odassa and Ughetto 2011, Lui 2011, Dorris 2003, Calderini and Odasso 2008, Gabala Jr 2004, and Hillery 2004. Patent securitization to date has remained highly geographically concentrated in the USA, most likely due to the maturity of its financial market (Lamoreaux et al. 2013; (Calderini and Odasso 2008). Yet, there is tremendous potential for developing countries because firms in emerging economies can export their patents to developed markets to be securitized according to predictable and functioning market instruments, rather than try to import a range of required investment rules and institutions. While domestic capacity building is essential, securitization increases access to capital immediately and experience with structuring these deals should improve capabilities. Up-front payment in the early stages of technology development can be more useful to a company than future revenue streams or delayed sale revenues. Patent securitization basically gives patent owners access to better funding conditions than corporate alternatives in terms of both duration and flexibility of funding contracts (Kirsh 2005). The centrality of patent protection to the emergence and evolution of technology markets is clear.

However, secondary technology markets, such as patent securitization deals, are embedded in a larger range of institutions. Regulatory bodies, courts, laws related to bankruptcy, companies, securities, antitrust and tax must all be able to cope with these new forms of monetization. Patent monetization techniques such as securitization and exchanges (discussed below) are relatively sophisticated and their utility to developing countries will depend on the degree to which these institutions and laws have developed. Other monetization strategies tailored to risk sharing, such as loan or royalty-based participation, rely on less sophisticated laws and institutions. By creating spin-off corporations based on technologies, patents can also be monetized in the form of shares and thus contribute to generating profits. These less elaborate strategies can also be a valuable way to monetize patents via trade secrets and proprietary know-how, which do not rely on legal institutions to the same degree. It is not within the scope of this paper to evaluate the threshold where this occurs but we believe evaluating the feasibility and applicability of these approaches for developing nations is an important avenue for future research.

\subsection{Patent Exchanges}

The incredible growth in the value of patents globally has not been adequately matched with increased levels of funding for R\&D in the developing world. Developing countries encounter two challenges: they must manage risks associated with innovation and they are largely unable to tap the full range of institutional investors because of their relatively undeveloped capital markets. Firms around the globe are missing out on valuable capital resources as a result of the inability to properly value and exchange their patents. Patents remain a highly illiquid asset and there is substantial difficulty in exploiting patents to generate greater cash flow.

The development of a liquid and robust exchange for patents is a vital step to ensure that firms gain alternative forms of finance for innovation (Ughetto and Odasso 2010). Financial exchanges for patents enable non- or under-utilized patents to be traded in a transparent marketplace. An exchange is valuable because it makes patents available to those that are in the best position to monetize them. Firms in the developing world may own valuable product and service patents but have insufficient complementary assets to monetize them. The complementary assets of large multinational firms results in high barriers to entry for innovators in the developing world, who do not benefit from the same economies of scale and scope. An effective exchange mechanism for patents reduces the need for complementary assets to commercialize a product. Exchanges thus enable innovating firms to monetize their rights without the considerable capital outlays traditionally associated with this (Serrano 2006; Chesbrough 2006). Formal secondary markets for patents are believed to level the competitive playing field by lowering entry barriers and undermining privileged access to technology (Arora, Fosfuri, and Gambardella 2001). As such, they are a powerful tool for actors in the developing world to monetize their patent rights. Again, as with patent securitization, this type of secondary market is embedded, and relies on, a set of financial and regulatory institutions. The extent to which developing nations are able to leverage this tool to their advantage is likely to be conditioned by the degree of sophistication of these institutions. 
Patent exchanges encounter a number of difficulties that the exchange of other commodities does not because of the nature of the rights being traded. Patent rights are by definition a claim to unique and novel technologies. The rights traded are thus extremely heterogeneous. Trading patents is not like trading sacks of rice or bars of gold. A lack of common valuation standards and a multitude of different types of rights complicate the process of turning patents into a standardized and tradable commodity. Patents cannot be efficiently traded in a transparent market space until there are adequate standards for valuing it (Hagelin 2002). The valuation of patents is an extensive subject of research and is elaborated on by Collan and Hekkila 2011, Mihara 2012, Lanjouw et al 1998, Mard et al. 2000, Hagelin 2002, and Reilly and Schweihs 2004. Efficient patent exchanges rely on adequate information about the underlying rights traded and necessitate substantial due diligence in order to vet the traded assets. This process can result in significant information asymmetries that benefit larger actors during the bargaining process. The importance of some patents to firm performance also suggests that companies may only selectively exchange patents of minor value rather than engage in deals relating to their core business strategies.

The Intellectual Property Exchange International (IPXI) is one intermediary that has attempted to establish such an exchange platform for patent rights. Standardized Unit License Right (ULR) contracts enable patent owners to license their technology in a non-discriminatory way to a variety of interested parties. The contracts provide potential buyers with a host of important purchasing information relating to the technology offered, the initial target price, and the quantity of contract units offered. Buyers of ULRs must report consumption behaviour to IPXI, which acts as the central monitoring and enforcement agency for the marketplace. The administrative responsibilities of IPXI, and the exchange platform facilitating the sale of patent rights commoditized through the ULR contract, reduce inefficiencies in bilateral technology transfer resulting from time, financial costs, redundancy problems and uncertainty of outcomes. ULRs may become an important liquidity alternative to normal equity and thus aid the monetization of patent rights. In spite of that, IPXI has seen hardly any trading volume.

While online portals may be currently headquartered in developed economies, there is nothing stopping actors in the developing world from leveraging these digital platforms to their own benefit. The recent founding of the Shanghai Silicon IP Exchange (SSIPEX) in China is a good example for this.

SSIPEX acts as a center for the transfer of patent related to semiconductors. It serves as a distribution channel for semiconductor technology owners and a demonstration center for local firms in order to help them assess which, if any, technology is suitable for their next product (Chesbrough 2011). It works with owners of semiconductor technologies in order to aggregate databases of manufacturing design tools, reference designs and other information. Foreign companies own $70 \%$ of the patents made available through SSIPEX and domestic firms own the remaining $30 \%$ (Chesbrough 2011). Chinese companies are invited to assess the technology and SSIPEX brokers a license agreement if the Chinese firm wishes to integrate the technologies into new products. Crucially, SSIPEX is open to all members and does not discriminate according to which foundry is eventually used in the manufacturing process. Revenue comes from membership fees charged for access to the patent databases, fees charged for displaying patents on the exchange, and fees for transaction brokerage between members and patent owners. A laboratory was established in 2006 inside SSIPEX to manufacture prototypes based on design brought by members. Functioning as a type of innovation black box, it prevents members from seeing exactly how the output was manufactured and it prevents them from reverse-engineering it. This enables prospective buyers to get more information relating to the patents while still protecting owners' rights (Chesbrough 2011).

However, with only 2752 patents focusing on integrated circuit technologies from 87 vendors and manufacturers in its core database (SSIPEX), the SSIPEX has not achieved the critical mass needed to make an exchange platform particularly efficient. While it is certainly an important center for technology transfer, its patent database may not be sufficiently developed to stimulate participation. There is a typical chicken/egg problem in this aspect of any exchange. An efficient market will stimulate participation, but an efficient market relies on adequate levels of participation. Another important challenge is the need for anonymity. The publication of patent details and the desire to exchange them can be used as competitive intelligence in many industries. Anonymity is required to maintain competitive strategies and avoid risks of litigation (Arora, Fosfuri, and Gambardella 2001). Companies may be seeking patents to protect product lines from infringement lawsuits. An unsuccessful bid for a patent license could turn a firm into a litigation target. Participants must be assured that the exchange intermediary adequately protects sensitive data while making enough information accessible to attract potential buyers. These are difficult trade-offs, since any exchange of patent rights relies on effective and comprehensive due diligence procedures and compliance monitoring mechanisms. Like IPXI SSIPEX does not possess the resources necessary to monitor the compliance of its small Chinese members with relevant patent laws. A member could gain access to a valuable technology and then transfer it to others without proper authorization, thus inhibiting the development of IPXI or SSIPEX as uncertainty 
about enforcement stops patent owners from making their technologies available (Chesbrough 2011). Strengthening the institutional context in which these actors operate may go a long way in fostering security and certainty for patent owners willing to license their technologies.

\subsection{Technology Transfer Offices}

The use of licensing in the developing world is frustrated by thin markets for technology. First and foremost, adequate patent enforcement is necessary in order for the patent system to act as an enabling environment for generating more licensing revenue. Companies must be assured that other will pay for licenses and will not simply steal technology. Yet, enforcement must be pursued in tandem with a more comprehensive approach to technology commercialization, which recognizes the importance of an innovation eco-system consisting of technology parks, venture capital and monetization support services.

When nations lack adequate market-driven processes to spur licensing revenue, technology transfer offices should step in to foster stronger innovation ecosystems. Many developing countries have established TTOs to provide financial support, training, identify potential alliances, brokerage services, and legal advice during licensing and equipment purchases. It is common for these offices to provide FDI-related technology transfer incentives to multinational corporations in an effort to increase the flow of technology into their borders. FDI incentive programs often include mandatory provisions for the training of local actors and the establishment of long-term business partnerships (UNCTAD 2004). This is necessary because, although FDI is an important channel for the transfer of technology, it does not guarantee efficient transfer unless it guarantees a level of commitment to local capacity building. Dedicated financing services in technology transfer offices can also provide venture capital support to local actors. Studies suggest that the rate of successful technology transfer offices can vary greatly depending on the level of socio-economic development within a country (Jafarieh 2001). While strong patent protection may result in net licensing imports in the short-term, effectively managed technology transfer offices can help importing countries acquire critical know-how and stimulate commercial capacity in the long term.

As experience with technology transfer offices grows, many offices are implementing a range of sophisticated mechanisms to ensure TTOs act as an enabler of patent commercialization. The Society for Technology Management (STEM) is a good example in that regard. As a non-profit organization recently created in Hyderabad, India to promote best practices in technology transfer offices and foster commercialization ecosystems is one of the initiatives that has been jointly funded by SARIMA, AUTM and IFTTO. The global network of IFTTO members is a particularly useful starting point for policy makers in developing nations to familiarize themselves with the practice of technology transfer offices and patent monetization.

The Industrial Technology Research Institute is another strong example of a successful technology transfer office. The Industrial Technology Research Institute (ITRI) was founded in Taiwan in 1973 and tasked with conducting and promoting research and development with the aim of increasing economic value in a number of important technology fields. Originally government-funded, the institute has been so successful that it is now entirely financially independent (Lee et al. 2009).

ITRI staff was pivotal in early spin-off efforts in semiconductor manufacturing. UMC and TSMC, the largest semiconductor firms in Taiwan, were established as 'spin-in' companies. Staff turnover with the private sector has been significant, with turnover rates reaching $15-20 \%$ in recent years (Lee et al. 2009). This staff turnover between the ITRI and firms that commercialize R\&D in the private sector is an effective way of supporting the commercialization process since the transfer of know-how, skills and technical knowledge is an integral part of effective technology transfer offices (Arora 1995; Gertler 2003). So far, it has helped small businesses gain access to over $\$ 8$ million of government funding by helping them apply to the Small Business Innovation Research program (ITRI). The ITRI has held over 163 training courses for over 8,000 participants in the last eight years and developed numerous multi-lateral technology cooperation agreements with major international firms. In 2009 alone, it conducted over 15,300 cases of R\&D services and facilitated technology transfer to Taiwan's private sector in over 1,100 cases; (Lee et al. 2009).

Patent management and monetization is a key component of what ITRI does. Aiding the process of patent aggregation among firms is one strategy ITRI uses to help monetize patents more efficiently in Taiwan (Shih 2005). The TFT-LCD (thin film transistor - liquid crystal display) alliance is a strong example of this monetization model. In 1990, ITRI aligned with the Taiwan TFT-LCD Association and seven of its subsidiaries to form a pooled patent portfolio of over 200 patents relating to flat-panel displays (Lee et al. 2009). This enabled local Taiwanese companies to enter the flat-panel display industry quite late, despite the significant barriers to entry posed by Japanese and South Korean competitors. By facilitating cross-licensing deals with these competitors using the patent 
pool created through the alliance, ITRI was integral to the development of this now lucrative industry in Taiwan (Shih 2005). The activities of the ITRI show the multiple strategies that can be implemented to facilitate domestic $\mathrm{R} \& \mathrm{D}$ and commercialization capacity.

Technology transfer offices have proliferated around the globe rapidly since the TRIPS Agreement. As developing countries continue to consolidate their patent regimes, technology transfer offices play an important role in attracting foreign companies with valuable patents into their borders and supporting domestic innovation processes by fostering extensive working relationships. Yet, simply attracting FDI and licensing patents in is insufficient. A number of coordinated mechanisms can help to aid the process of also licensing technology out. Technology transfer offices should learn from the experiences of successful initiatives like the ITRI in pursuing their goal of helping local firms to access new technologies and monetize them. Policy makers must appreciate the value of TTOs and recognize the different roles that they can achieve. A TTO can limit its focus to helping negotiate flexible licensing terms and setting suitable research commercialization policies. It could extend this role to help form a licensee by supporting business plan development, securing funding and recruiting talent. It could even go a step further and participate directly in business operations and investment. The ITRI approach represents the latter, where research, development and monetization processes have been rolled into a single entity in order to promote technology transfer and licensing revenue in a specific industry. Establishing TTOs in developing nations and integrating them into the global network of technology transfer associations is a powerful instrument to support commercialization processes domestically by systematically sharing experiences, information and practices relating to licensing. It will increase awareness among start-ups and research institutions of the role and practice of licensing in promoting active markets for technology.

\subsection{Patent Litigation Support}

The rise of non-practicing entities (NPE) that accumulate large patent portfolios in order to monetize these assets through litigation procedures has been a controversial development in recent years. These pejoratively-labelled 'patent trolls' accumulate patent portfolios solely for the purposes of infringement lawsuits and license fees. Major international NPEs such as Intellectual Ventures are estimated to own between 10,000 - 15,000 patents (Patent Freedom 2013). Estimates of the loss in market capitalization resulting from NPE lawsuits in software alone over the past twenty years put the cost at $\$ 0.5$ trillion (Tiller 2011).

As patent infringement lawsuits create significant operating uncertainty in technology markets, the threat of lawsuits can stop innovating firms from commercializing potentially valuable technologies. While multinational firms with large patent portfolios and defensive patent pools have some strategies available to defend themselves against NPE litigation, SMEs, particularly in the developing world, are more at risk. Limited financial, legal and human resources means SMEs cannot respond to these threats as effectively and thus face significant barriers to entry in global technology markets. In a context where firm capacity to respond is weaker, there is a strong case for more active support from government departments or other public agencies (Lee et al. 2009). This said there are also important examples of non-practicing entities that have been used to support innovation in competitive industries, rather than litigate against operating firms. The Open Invention Network acquires patents and licenses them royalty-free to companies, institutions or individuals in return for agreements that these actors will not assert patents against the Linux system. This enables companies to invest in Linux infrastructure and related products without fear of infringement liability, fuelling innovation and growth around this technological ecosystem.

The Republic of Korea's government has also experimented with multiple types of support to aid Korean SMEs in their IPR disputes with international firms. Initially, this was in the form of direct cost-sharing initiatives between SMEs and the government regarding IPR disputes. The substantial cost of legal proceedings in IPR disputes would have meant that Korean SMEs seeking to commercialize a technology would encounter significant barriers to monetizing their patents. By distributing the cost, this initiative provided critical support to SMEs at the early stage of technology commercialization. The Republic of Korea's government has helped fund the creation and sale of commercial patent insurance that covers the cost of potential infringement lawsuits. This enables start-ups to operate with reduced uncertainty and increased cash flows at the early stages of development. The Republic of Korea's government pays $70 \%$ or more of the premium for patent insurance, thus reducing the burden for SMEs and stimulating domestic innovation in the Republic of Korea. The government also supports SMEs in the process of market and export investigations to determine the probability of lawsuits when these companies wish to export their products to new markets.

IPR disputes between SMEs and foreign entities within the domestic market are also supported. Over 42 SMEs employed this service in 2009 (Lee et al. 2009). Help is provided in terms of analysis of legal patent documents, 
infringement claims, counterclaims and continuous support during legal processes. The government also supports SMEs in deciding on how to monetize their patents by providing consultancy on alternative licensing arrangements and patent pools. It has also fostered the development of a patent angel - a public-private consortium fund - that manages a set of IPRs for a group of SMEs. These SMEs pay membership fees or invest capital to become equity holders in the group, whose patent umbrella effectively defends SMEs in their proceedings with patent trolls and other infringement lawsuits (Lee et al. 2009). The Presidential Council on National Competitiveness recently reviewed the fact that Balance of Payments for trading technologies was negative, despite ranking fourth globally in terms of patent ownership. To promote funding for domestic innovation, the Council announced it would create a $\$ 18$ million fund to launch a management company for patents and will jointly invest with private actors up to $\$ 460$ million to start a Korean-based NPE. The budget for commercializing home-grown technologies was also raised from $0.7 \%$ to $3 \%$ of total R\&D spending (Chosunilbo 2009). These initiatives serve as an important model for the developing world, which must support the commercialization of patents in order to progress from being mere patent owners to patent strategists.

\section{Conclusions}

Despite the closing gap in patent ownership in technologically sophisticated developing countries, a significant gap in patent commercialization remains. The same economies that are becoming global leaders in terms of the size of their patent portfolios suffer from a lack of corresponding increase in their financial returns from innovation. While traditional bilateral licensing remains an important mechanism to monetize patents, there are a number of other mechanisms available to generate value from patents. This paper has briefly outlined a few of these mechanisms, by reference to several case studies, and discussed the ways in which patent monetization can be improved in the developing world. Significantly, patent monetization can be stimulated using both market mechanisms and carefully structured government support. It is this combination of a positive institutional environment for patent commercialization and an awareness of the market mechanisms available to innovators that will promote stronger technology markets and generate more financial returns from patents in the developing world.

Patent exchanges and patent securitization are two market-driven commercialization processes that present valuable opportunities for actors in developing countries. Although exchanges and securitization deals occur primarily in developed economies, there is no reason that developing countries cannot leverage these mechanisms to access crucial funding opportunities to commercialize their technology. As firms in developing countries begin utilizing these platforms, they will gain direct access to investment and simultaneously bolster their patent monetization capacity. Experience with these mechanisms will be an important step in establishing functioning technology markets. The point is not to continue relying on institutions in the developed world, but to gradually develop capacity while still gaining direct access to important capital markets and monetization strategies. Public-private initiatives, such as the Industrial Technology Research Institute in Taiwan and the coordinated litigation support and defensive patent pools evident in the Republic of Korea, are also integral to closing the patent monetization divide. By promoting domestic technology markets, fostering knowledge spillovers, and implementing a range of tools to lower barriers to entry to international markets for actors in the developing world, these initiatives represent some of the ways to foster a more equitable global patent system. Policy makers should leverage existing networks of technology transfer professionals, such as AUTM or the IFTTO, to facilitate this process and share experiences, practices and information relating to technology transfer.

Patent owners in the developing world are not just passive recipients of proprietary innovation developed elsewhere. The evidence suggests that they are active participants in the global system who are beginning to increase their ownership of patents. As patent owners they now face the challenge of how to exploit and commercialize their assets. While recognizing that developing countries face distinct institutional challenges, it is equally true that they have ample opportunities to leverage the international patent system to promote economic growth. Alternative patent monetization methods - like exchanges, securitizations and defensive pools - are still a relatively new phenomenon. Though developing countries are at different stages of consolidating the ecosystem of institutional, legislative and market infrastructure that helps stimulate ownership and commercialization of patents, greater awareness of emerging patent monetization techniques will expand the range of options available to domestic actors. Naturally, a minimum level of patent enforcement, institutional development, and market sophistication is needed to fuel patent commercialization. Developing nations are certainly not homogeneous in this respect. Identifying the threshold for patent commercialization and understanding how to help countries attain would be an important avenue for future research. 


\section{References}

Anson, W. (2005). Intangible Assets: A New Source of Security and Securitization. The Secured Lender, Jul/Aug 2005.

Arora, A. (1995). Licensing tacit knowledge: intellectual property rights and the market for know-how. Economics of innovation and new technology, 4(1), 41-60.

Arora, A., A. Fosfuri, et A. Gambardella. (2001). Markets for technology and their implications for corporate strategy. Industrial and Corporate Change, 10(2), 419.

Bell, Martin. (2012). International Technology Transfer, Innovation capabilities and sustainable directions of Development. Low-Carbon Technology Transfer: From Rhetoric to Reality, 20.

Bettig, R.V. (1996). Copyrighting Culture: The Political Economy of Intellectual Property. Boulder: Westview Press.

Borod, R. S. (2005). An update on intellectual property securitization. The Journal of Structured Finance, 10(4), 65-72.

Bozeman, B. (2000). Technology transfer and public policy: a review of research and theory. Research policy, 29(4-5), 627-656.

Calderini, Mario, \& Maria Cristina Odasso. (2008). Intellectual Property Portfolio Securitization: An Evidence Based Analysis. SSRN eLibrary. Retrieved from http://papers.ssrn.com/sol3/papers.cfm?abstract_id=1314805

Chen, Y., et T. Puttitanun. (2005). Intellectual property rights and innovation in developing countries. Journal of development economics, 78(2), 474-493.

Chesbrough, H. (2006). Emerging secondary markets for Intellectual Property. Research Report to National Center for Industrial Property Information and Traning (NCIPI).

Chosunilbo. (2009). President, Council Forge Roadmap for Intellectual Property Competitiveness. Retrieved from http://english.chosun.com/site/data/html_dir/2009/07/30/2009073000563.html

Collan, Mikael, \& Markku Heikkilä. (2011). Enhancing Patent Valuation with the Pay-off Method. Journal of Intellectual Property Rights, 16(5), 377-84.

Dang, Jianwei, \& Kazuyuki Motohashi. (2012). Patent Value and Liquidity: Evidence from Patent-Collateralized Loans in China.

Dechezleprêtre, Antoine, Matthieu Glachant, Ivan Haščič, Nick Johnstone, et Yann Ménière. (2011). Invention and Transfer of Climate Change-Mitigation Technologies: A Global Analysis. Review of Environmental Economics and Policy, 5(1), 109-130.

Dorris, M. S. (2003). The securitization of drug royalties: a new elixir. First published in Global Securitisation and Structured Finance.

Edwin L.-C., Lai. (1998). International intellectual property rights protection and the rate of product innovation. Journal of Development Economics, 55(1) (février), 133-153. http://dx.doi.org/10.1016/S0304-3878(97)00059-X.

Feldman, M. P, et R. Florida. (1994). The geographic sources of innovation: technological infrastructure and product innovation in the United States. Annals of the Association of American Geographers, 84(2), 210-229.

Fukugawa, Nobuya. (2012). Impacts of Intangible Assets on the Initial Public Offering of Biotechnology Startups. Economics Letters, 116(1), 83-85.

Gabala Jr, J. M. (2004). Intellectual Alchemy: Securitization of Intellectual Property As an Innovative Form of Alternative Financing. John Marshall Review of Intellectual Property Law, 3, 307-323.

Gertler, M. S. (2003). Tacit knowledge and the economic geography of context, or the undefinable tacitness of being (there). Journal of economic geography, 3(1), 75.

Gould, David M., et William C. Gruben. (1996). The role of intellectual property rights in economic growth. Journal of Development Economics, 48(2) (mars), 323-350. http://dx.doi.org/10.1016/0304-3878(95)00039-9

Hagelin, T. (2002). New Method to Value Intellectual Property, A. AIPLA Quarterly Journal, 30(3), 353-403.

Hagiu, Andrei, \& David B Yoffie. (2013). The New Patent Intermediaries: Platforms, Defensive Aggregators, and 
Super-Aggregators. The Journal of Economic Perspectives, 27(1), 45-65.

Helfer, L.R. (2004). Regime shifting: the TRIPS agreement and new dynamics of international intellectual property lawmaking. Yale J. Int'l L., 29, 1.

Helpman, E. (1992). Innovation, imitation, and intellectual property rights. National Bureau of Economic Research.

Henderson, Rebecca, Adam B. Jaffe, et Manuel Trajtenberg. (1998). Universities as a Source of Commercial Technology: A Detailed Analysis of University Patenting, 1965-1988. Review of Economics and Statistics, 80(1), 119-127. http://dx.doi.org/10.1162/003465398557221

Hewitt-Dundas, Nola. (2011). The role of proximity in university-business cooperation for innovation. The Journal of Technology Transfer, (juillet 24). http://dx.doi.org/10.1007/s10961-011-9229-4

Hillery, J. S. (2004). Securitization of intellectual property: recent trends from the United States. Washington CORE consulting firm report, March.

James, R, Markusen. (2001). Contracts, intellectual property rights, and multinational investment in developing countries. Journal of International Economics, 53(1) (février), 189-204. http://dx.doi.org/10.1016/S0022-1996(00)00058-1

Lamoreaux, Naomi R, Kenneth L Sokoloff, \& Dhanoos Sutthiphisal. (2013). Patent Alchemy: The Market for Technology in US History. Business History Review, 87(01), 3-38.

Lanjouw, J.O., et J. Lerner. (1997). The enforcement of intellectual property rights: a survey of the empirical literature. National Bureau of Economic Research.

Lee, Keun, Kyooho Park, Jun-Byoung Oh, et Jinyoung Kim. (2009). Economics of IP in the Context of Shifting Innovation Paradigm. WIPO Annual Report.

Liu, Wei. (1995). International technology transfer and development of technological capabilities: A theoretical framework. Technology in Society, 17(1), 103-120. http://dx.doi.org/10.1016/0160-791X(94)00028-C

Lui, Alison. (2011). Multiple Principal-Agent Problems in Securitisation. Poznan University of Economics Review, $11(2)$.

Malackowski, J. E. (2006). The Intellectual Property Marketplace: Past, Present and Future. J. Marshall Rev. Intell. Prop. L., 5, 605-641.

Maskus, Keith E., et Jerome H. Reichman. (2004). The Globalization of Private Knowledge Goods and The Privatization of Global Public Goods. Journal of International Economic Law, 7(2), 279-320.

May, C. (2009). The global political economy of intellectual property rights: the new enclosures.

May, Christopher. (2002). Trouble in E-topia: Knowledge as Intellectual Property. Urban Studies, 39(5-6), 1037-1049.

McClure, I. D. Commoditizing Intellectual Property Rights: The Practicability of a Commercialized and Transparent International IPR Market and the Need for International Standards. Buffalo Intellectual Property Law Journal, 6, 1.

Merges, R. P. (1994). Of property rules, coase, and intellectual property. Columbia, 94, 26-55.

Merges, R. P. (1999). Intellectual property rights, input markets, and the value of intangible assets. Draft, February.

Mihara, Kenji. (2012). Considerations on Patent Valuation Based on Patent Classification and Citation in Biotechnological Field. Journal of Information Processing and Management, 54, 738-49.

Millien, R., et R. Laurie. (2007). A Summary of Established \& Emerging Business Models . The Sedona Conference Phoenix. AZ.

Mowery, D., et B. Sampat. (2005). The Bayh-Dole Act of 1980 and University-Industry technology transfer: a model for other OECD governments? Essays in Honor of Edwin Mansfield, 233-245.

Mowery, D.C., R.R. Nelson, B. Sampat, et A.A. Ziedonis. (1999). The effects of the Bayh-Dole Act on US university research and technology transfer: An analysis of data from Columbia University, the University of California, and Stanford University. Research Policy, 29, 729-40.

Mowery, David C., et Arvids A. Ziedonis. (2002). Academic patent quality and quantity before and after the Bayh-Dole act in the United States. Research Policy, 31(3) (mars), 399-418. 
http://dx.doi.org/10.1016/S0048-7333(01)00116-0

Noveck, B. S. (2006). Peer to Patent: Collective Intelligence, Open Review, and Patent Reform. Harvard Journal of Law \& Technology, 20(1), 123-162.

Odasso, Maria Cristina, \& Elisa Ughetto. (2011). Patent-backed Securities in Pharmaceuticals: What Determines Success or Failure? R\&D Management, 41(3), 219-39.

Ortiz, Miguel Angel Axtle. (2011). Intellectual Capital (intangible Assets) Valuation Considering the Context. Journal of Business \& Economics Research (JBER), 4(9).

Pueyo, Ana, Rodrigo García, María Mendiluce, \& Darío Morales. (2011). The Role of Technology Transfer for the Development of a Local Wind Component Industry in Chile. Energy Policy, 39(7), 4274-83.

Reilly, R. F, et R. P Schweihs. (2004). The handbook of business valuation and intellectual property analysis. McGraw-Hill.

Saggi, Kamal. (2002). Trade, Foreign Direct Investment, and International Technology Transfer: A Survey. The World Bank Research Observer, 17(2), 191-235.

Schrank, Andrew. (2004). Ready-to-Wear Development? Foreign Investment, Technology Transfer, and Learning by Watching in the Apparel Trade. Social Forces, 83(1), 123-156.

Scott, Shane. (2004). Encouraging university entrepreneurship? The effect of the Bayh-Dole Act on university patenting in the United States. Journal of Business Venturing, 19(1) (janvier), 127-151. http://dx.doi.org/10.1016/S0883-9026(02)00114-3

Serrano, C. J. (2006). The market for intellectual property: Evidence from the transfer of patents. University of Minnesota.

Teece, D. J. (1977). Technology Transfer by Multinational Firms: The Resource Cost of Transferring Technological Know-How. The Economic Journal, 87(346) (juin 1), 242-261.

The Economist. (2010). Innovation in China. Patents Yes, Ideas Maybe. Retrieved from http://www.economist.com/node/17257940

Tiller, Rob. (2011). The huge societal costs of NPE software patent lawsuits. Retrieved from $\mathrm{http}: / /$ opensource.com/law/11/9/ginormous-losses-npe-software-patent-lawsuits

Trajtenberg, Manuel. (1990). A penny for your quotes: patent citations and the value of innovations. RAND Journal of Economics (RAND Journal of Economics), 21(1), 172-187.

Ughetto, E., et C. Odasso. (2010). Patent Value: Seller and Bidder Perspectives. Working Paper, Politecnico di Torino

Watanabe, H. (2004). Intellectual Property as Securitized Assets,. The Institute of Intellectual Property, March 2004.

Yanrong, Hong. (2013). New Study on the Securitization of the Right of Charge of Patent License: From the Perspective of Asset-Credit Financing and Risk Management. Intellectual Property, 11, 013.

Ziedonis, R. H. (2004). Don't fence me in: Fragmented markets for technology and the patent acquisition strategies of firms. Management Science, 50(6), 804-820.

\section{Note}

Note 1. Research funding was received from the World Bank. 